\title{
Canine oviductal exosomes improve oocyte development via EGFR/MAPK signaling pathway
}

\author{
Seok Hee Lee ${ }^{1,2}$, Hyun Ju Oh${ }^{1}$, Min Jung Kim and Byeong Chun Lee ${ }^{1}$ \\ ${ }^{1}$ Department of Theriogenology and Biotechnology, College of Veterinary Medicine, Seoul National University, \\ Seoul, Republic of Korea and ${ }^{2}$ Center for Reproductive Sciences, Department of Obstetrics and Gynecology, \\ University of California San Francisco, San Francisco, California, USA
}

Correspondence should be addressed to B C Lee: Email; bclee@snu.ac.kr

\begin{abstract}
Oviduct cells produce a favorable environment for the development of gametes by generating multiple growth factors. Particularly, in canine species, immature oocytes undergo serial maturation processes in the oviduct, while the other mammals already possess matured oocytes in ovulatory follicles. However, little is known about the potential effect exhibited by the components released from canine oviduct cells (OCs) for modulating the biological function of oocytes. Recently, exosomes are regarded as promising extracellular vesicles because they represent considerable data for molecular cargo. Therefore, we first investigated the effect of canine oviductal exosomes (OC-Exo) on oocyte development via EGFR/MAPK pathway. Our results showed that OC-Exo labeled with PHK67 are successfully incorporated with cumulus cells and oocytes during IVM. Also, OC-Exo markedly increased the proportion of cumulus-oocyte complexes (COCs) exhibiting cumulus expansion as well as cumulus cell proliferation and maturation rate of oocytes $(P<0.05)$. Furthermore, gene expression patterns related with EGFR/MAPK pathway including EGFR, PKA, TACE/ADAM17, MAPK1/3, MAPK14, PTGS2, TNFAIP6, GDF9, and BMP15 were positively modified in COCs cultured with OC-Exo $(P<0.05)$. In addition, OC-Exo significantly up-regulated the protein expression levels of p-EGFR, p-MAPK1/3, GDF9 and BMP15 in COCs $(P<$ 0.05). Consequently, the current study provides a model for understanding the roles of OC-Exo as bioactive molecules for canine oocyte maturation via EGFR/MAPK pathway, which would open a new avenue for the application of exosomes to improve assisted reproductive technology in mammals, including humans.

Reproduction (2020) 160 613-625
\end{abstract}

\section{Introduction}

The establishment of in vitro maturation (IVM) of canine oocytes has been limited due to their unique reproductive physiology. Unlike other mammals' in vivo oocyte maturation process, canine oocytes stay in the immature state after ovulation, and they complete the first meiosis in the oviduct within $72 \mathrm{~h}$ (Holst \& Phemister 1971, Tsutsui 1989). In order to simulate the in vivo environment for oocyte maturation, a variety of studies have introduced the oviductal elements, including synthetic oviductal fluid to the culture medium (Hewitt \& England 1998), such as co-culturing canine oviduct cells with oocytes (Bogliolo et al. 2002, Vannucchi et al. 2006, Lee et al. 2017), creating a similar environment by inducing low oxygen tension or presence of $10 \%$ bitch serum (Nickson et al. 1993, Songsasen et al. 2002). However, the oocyte maturation rate is still poor (average 10\%) (Luvoni et al. 2005) due to the lack of understanding of in vivo reproductive conditions in the bitch (Luvoni et al. 2005). Recently, we demonstrated that the canine oviduct cell co-culture system improved the maturation rate of oocytes in canine and porcine species as well as enhanced the developmental competence of porcine embryos via EGFR/MAPK signaling pathway, an essential mechanism for oocyte development (Lee et al. 2017, 2018). Accordingly, we aimed to identify the relationship between canine oviduct cells and oocytes and their specific mechanism that induces in vitro maturation. As various types of growth factors, proteins, and receptors are secreted in the culture medium, the conditioned medium would play an important role in oocyte development (Rieger et al. 1995, Maillo et al. 2016). Although many soluble factors or extracellular vesicles (EVs) are released into the extracellular space, information about their existences and effects on gametes are still elusive.

Extracellular vesicles, including exosomes, microvesicles, and apoptotic bodies, have been considered as important mediators in cell-to-cell communication (Hoshino et al. 2015, Zhang et al. 2015). In particular, exosomes are lipid bilayer vesicles with a size of 30-200 nm, and they are released into the extracellular environment by the fusion of 
a multi-vesicular body with the cell membrane (EI Andaloussi et al. 2013, Haney et al. 2015). It has been demonstrated that the exosome-transported molecular cargos, such as mRNA, microRNA, DNA, and lipids, could affect the target cells by inducing alterations in their physiological functions and mediating cellular pathways (Valadi et al. 2007, Kosaka et al. 2010, Quesenberry \& Aliotta 2010). Regarding the maternal tracts, including oviductal canal and uterus, they have been shown to regulate gamete and embryo interaction by altering transcript abundance (AI-Dossary \& MartinDeleon 2016, Burns et al. 2016, Di Pietro 2016). However, there are only a few studies on the effect of exosomes on gamete/embryos, whereas no study has provided extensive information on the secretion/ content of oviductal exosomes and their effect on oocyte maturation. As exosomes have emerged as potential biomarkers to improve reproductive success, the study of oviductal exosomes has the potential for expanding our knowledge of the reproduction biology. Therefore, in the present study, we evaluated the signals from OC-Exo to canine oocytes and investigated for the first time their effects on in vitro maturation of oocytes and cumulus expansion during IVM and the expression of genes/proteins related to EGFR/MAPK signaling pathway.

\section{Materials and methods}

\section{Chemicals}

All chemicals were obtained from Sigma-Aldrich Co. LLC. unless otherwise stated.

\section{Ethics of animal experiments}

In this study, oviduct cells were collected from 1- to 3-year-old mixed breed bitches in the estrus stage. Animal experiments were performed following a standard procedure established by the Committee for Accreditation of Laboratory Animal Care and the Guideline for the Care and Use of Laboratory Animals of Seoul National University (approval number; SNU-140704-1).

\section{Collection of canine ovaries and oocytes}

Ovaries from domestic bitches were collected during routine ovariohysterectomy at veterinary clinics. All ovaries were used with consent from the owners of these animals. The ovaries were transported to the laboratory in saline at $37^{\circ} \mathrm{C}$ within $30 \mathrm{~min}$ and immediately washed several times with PBS (Invitrogen) and minced with a surgical blade in HEPES-buffered tissue culture medium 199 (TCM-199; Invitrogen) supplemented with $2 \mathrm{mmol} / \mathrm{L} \mathrm{NaHCO}, 5 \mathrm{mg} / \mathrm{mL} \mathrm{BSA}$, and $1 \%$ penicillinstreptomycin. Thereafter, cumulus-oocyte complexes (COCs) were selected for the experiments based on morphological features as follows: (1) dark pigmented homogeneous cytoplasm, (2) more than two compact multilayers of cumulus cells, and (3) >100 $\mu \mathrm{m}$ in diameter (Lee et al. 2017).

\section{Collection and culture of canine oviduct cells from bitches in estrus stage}

Canine oviduct cells (OCs) were obtained by flushing method in estrus bitches (Lee et al. 2005). For flushing oviduct, a total of eight bitches in the estrus stage without clinical signs of disease were recruited. Briefly, canine oviduct cells (OCs) were obtained from anesthetized females by flushing method. The fimbria of the oviduct was accessed through the bursal slit using a cannula composed of an inverted flanged bulb steel needle mounted on an empty $10 \mathrm{~mL}$ syringe without the plunger, and the syringe was inserted into the oviduct to its end. Then, a hypodermic 24-gauge i.v. catheter filled with 10 $\mathrm{mL}$ of sterilized normal saline was cannulated into the caudal portion of the oviduct, and OCs were flushed out with normal saline by retrograde flushing with appropriate pressure. All dogs were thoroughly and continuously monitored after the surgery, and we confirmed that they recovered their health after the surgery. The oviduct flushing medium was centrifuged at $1960 \mathrm{~g}$ for $2 \mathrm{~min}$ and the pellet was collected. The pellets were resuspended in RCMEP medium (K-Stem Cell Research Institute, Seoul, Korea) and centrifugation was performed at $1960 \mathrm{~g}$ for $2 \mathrm{~min}$. After discarding the supernatant, the OCs were cultured up to passages 1 to 2 in RCMEP medium with $1 \mu \mathrm{g} / \mathrm{mL}$ of progesterone as previously described by our researches (Lee et al. 2019, 2020) and cryopreserved using $10 \%$ dimethyl sulfoxide and $90 \%$ fetal bovine serum (FBS; Gibco) in liquid nitrogen until further experiments.

\section{Collection of conditioned medium and isolation of oviductal exosomes}

First, OCs were seeded on culture dishes at the same volumes of the culture medium containing 10\% FBS with $1 \mu \mathrm{g} / \mathrm{mL}$ of progesterone. After culturing for $24 \mathrm{~h}$, the media were exchanged with serum-free medium (containing exosomedepleted FBS; System Biosciences, San Francisco, CA) with $1 \mu \mathrm{g} / \mathrm{mL}$ of progesterone. After an additional 24-h culture, the supernatant was collected and centrifugation was performed $\left(30 \mathrm{~min}, 2000 \mathrm{~g}, 4^{\circ} \mathrm{C}\right.$ ). For exosomes extraction, the Total Exosome Isolation Reagent (Life Technologies) was used according to the manufacturer's instructions. Briefly, to remove cell debris, the media were centrifuged at $2000 \mathrm{~g}$ for $30 \mathrm{~min}$. Thereafter, the supernatant was transferred to a tube and appropriate volumes of reagents were added. The mixture was incubated at $4^{\circ} \mathrm{C}$ overnight after vortexing. Then, the mixtures were centrifuged at $10,000 \mathrm{~g}$ for $1 \mathrm{~h}$; the pellet was resuspended in PBS and used for further experiments.

\section{Characterization of oviductal exosomes}

The OC-Exo were characterized using previously described experimental methods (Lee et al. 2019) as follows: (1) transmission electron microscopy (TEM), (2) nanoparticle tracking analysis (NTA), and (3) Western blot analysis. 
For TEM, $5 \mu \mathrm{L}$ of isolated exosomes suspensions were transferred to copper mesh Formvar coated carbon stabilized grids and the suspensions were absorbed in $5 \mathrm{~min}$. Then, the suspensions were wiped out and $5 \mu \mathrm{L}$ of $1 \%$ aqueous uranyl acetate was used to stain OC-Exo for $30 \mathrm{~s}$. Finally, the samples were allowed to air dry for $5 \mathrm{~min}$ and analyzed by using a transmission electron microscope (LIBRA 120, Carl Zeiss) at $110 \mathrm{kV}$. The NTA was performed with a Nanosight LM10 instrument (Nanosight, Malvern, UK) following the manufacturer's protocols to evaluate the concentration, intensity, and size in exosomes. For Western blot analysis, the proteins from exosomes were lysed, then the sample was heated at $95^{\circ} \mathrm{C}$ for $10 \mathrm{~min}$, and separated by $12 \%$ Tris-Tricine SDS-PAGE. The gels were transferred onto polyvinylidene difluoride membranes at $350 \mathrm{~mA}$ for $70 \mathrm{~min}$. After transfer, the gels were blocked with the $5 \%$ skim milk in Tris-buffered saline containing $0.05 \%$ Tween 20 (TTBS) for $1 \mathrm{~h}$ at room temperature (RT). The primary antibodies (anti-beta actin (1:2500, ab6276, Abcam) anti-CD9 (1:2500, sc-13118, Santa Cruz Biotechnology Inc) and anti-calnexin (1:2500, ab22595, Abcam) were added and incubated for overnight at $4{ }^{\circ} \mathrm{C}$ in TTBS. Then, the membranes were washed with TTBS and incubated with the secondary antibody rabbit anti-mouse IgG (1:5000, ab6728, Abcam) for $1 \mathrm{~h}$ at RT. After washing the membranes, the proteins were detected using the chemiluminescence reagent (West-Q ECL solution, GenDEPOT). Band density was quantitated by using Fusion Solo software (Vilber Lourmat, France).

\section{In vitro maturation of canine oocytes treated with canine oviductal exosomes}

The selected COCs were cultured in a four-well dish for $72 \mathrm{~h}$ at $38^{\circ} \mathrm{C}$ in a humidified atmosphere of $5 \% \mathrm{CO}_{2}$ in IVM medium, containing TCM-199 supplemented with $0.91 \mathrm{mM}$ sodium pyruvate, $0.57 \mathrm{mM}$ cysteine, $10 \%$ exosome-depleted FBS, $0.5 \mu \mathrm{g} / \mathrm{mL}$ follicle-stimulating hormone, and $0.5 \mu \mathrm{g} / \mathrm{mL}$ luteinizing hormone. In this study, three experimental groups were compared: (1) control, cultured COCs without OC-Exo treatment; (2) $25 \mu \mathrm{g} / \mathrm{mL}$, cultured COCs with $25 \mu \mathrm{g} / \mathrm{mL}$ OC-Exo treatment for $72 \mathrm{~h}$, and (3) $50 \mu \mathrm{g} / \mathrm{mL}$, cultured COCs with $50 \mu \mathrm{g} / \mathrm{mL}$ OC-Exo treatment for $72 \mathrm{~h}$. In this experiment, the OC-Exo pellet was resuspended in IVM medium and treated into COCs, while only the IVM medium was treated into the control group. Generally, the OC-Exo adhere very tightly to the surface of the tube after centrifugation; therefore, any small volume of residues in the extraction solution can be completely removed without disturbing the OC-Exo pellet. The IVM system applied in this study is described in Fig. 1A. For IVM experiment for oocytes culture, a total of 310 COCs were used in seven independent replicates and 20-56 COCs were used per repeat (control group: 103, $25 \mu \mathrm{g} / \mathrm{mL}$ OC-Exo group: 107, $50 \mu \mathrm{g} / \mathrm{mL}$ OC-Exo group: 100).

\section{Incorporation of oviductal exosomes into cumulus- oocyte complexes using uptake assay}

To trace the incorporation of OC-Exo into COCs during IVM, exosomes were labeled with a green fluorescent reagent (PKH67, Green Fluorescent Cell Linker Kit, Sigma Chemical Co.) as per the manual for 24, 48, and 72 h of IVM. In brief, OC-Exo pellets were resuspended in diluent $\mathrm{C}$ and PKH67 solution. After incubating for $5 \mathrm{~min}$ at RT, the labeling action was stopped by incubating for $1 \mathrm{~min}$ with $1 \mathrm{~mL}$ of exosome-free FBS. Then, the IVM medium was added and centrifugation was performed at $100,000 \mathrm{~g}$ for $30 \mathrm{~min}$ at $4{ }^{\circ} \mathrm{C}$. After discarding the supernatant, the pellets were resuspended in IVM medium supplemented with $10 \%$ exosome-free FBS and stored at $-30^{\circ} \mathrm{C}$. The COCs were cultured for $72 \mathrm{~h}$, while labeled exosomes were incubated with COCs for 24, 48, and 72 h, respectively. Exosome incorporation by COCs was evaluated under a fluorescence microscope. In total, 48 canine COCs were randomly selected and used in four independent replicates for the incorporation of labeled OC-Exo experiment and four COCs were used per repeat (control group: 16, $25 \mu \mathrm{g} / \mathrm{mL}$ OC-Exo group: 16, $50 \mu \mathrm{g} / \mathrm{mL}$ OC-Exo group: 16).

A

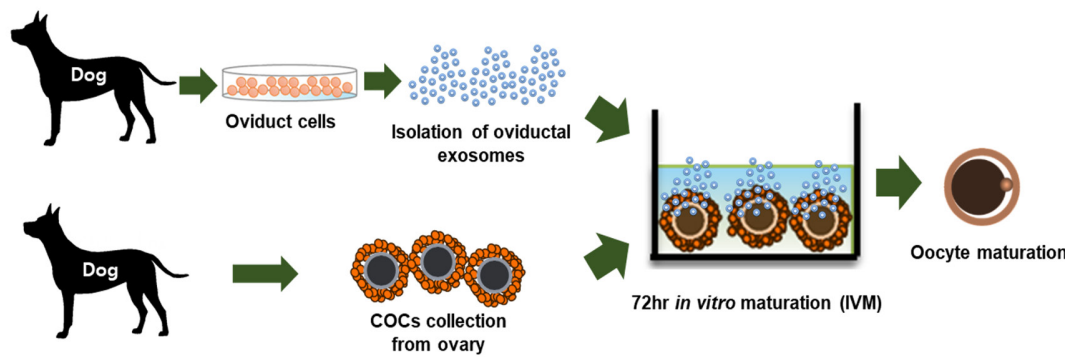

B

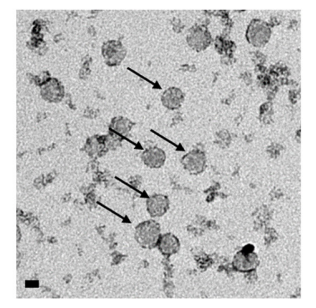

$\mathrm{C}$

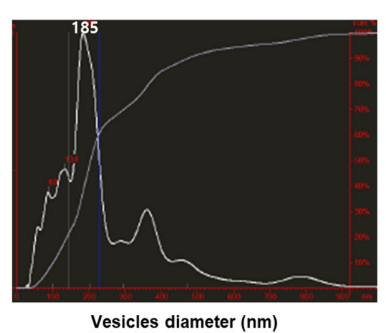

$\mathrm{D}$

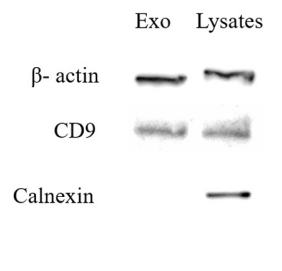

Figure $1 \mathrm{~A}$ schematic illustration of the experiment and characterization of oviductal exosomes derived from oviduct cells. (A) A schematic illustration of the experiment with canine oviductal exosomes and cumulusoocyte complexes. (B) Morphological characterization of exosomes isolated from oviduct cells using transmission electron microscopy; black arrows indicate exosomes (bar: $50 \mu \mathrm{m}$ ). (C) Characterization of exosomes using nanoparticle tracking analysis. (D) Identification of exosomal-specific marker (CD9) and negative calnexin endoplasmic reticulum marker from oviductal exosomes and cell lysates using immunoblotting. Exo, exosomes derived from oviduct cells; Lysates, lysates from oviduct cells. 


\section{Assessment of cumulus cell expansion}

The degree of cumulus expansion was assessed for 24, 48, and $72 \mathrm{~h}$ of IVM in oocytes with cumulus cells after different concentrations of OC-Exo treatment. The scoring system was as follows: no expansion, all layers of cumulus cells were tightly attached to the oocyte; small expansion, the two outer layers showed a little halo around the COCs; expanded, more than three layers of cumulus cells were expanded around the oocyte; and denuded, without any cumulus cells attached. In total, 210 randomly selected canine COCs were used in five independent replicates for evaluating the cumulus expansion experiment and 14 COCs were used per repeat (control group: 70, $25 \mu \mathrm{g} / \mathrm{mL}$ OC-Exo group: 70, $50 \mu \mathrm{g} / \mathrm{mL}$ OC-Exo group: 70$)$.

\section{Assessment of nuclear maturation}

After $72 \mathrm{~h}$ of IVM, COCs were denuded by gentle pipetting with $0.1 \%$ hyaluronidase to evaluate in vitro nuclear maturation rates. An extrusion of first polar body (Metaphase II) from each denuded oocyte was assessed under a stereomicroscope (TE2000-S; Nikon) and immature (without first polar body extrusion) and degenerated oocytes (irregular border and fragmentation of cytoplasm) were also classified. For IVM experiment for oocytes culture, a total of 310 COCs were used in seven independent replicates and 20-56 COCs were used per repeat (control group: 103, $25 \mu \mathrm{g} / \mathrm{mL}$ OC-Exo group: 107, $50 \mu \mathrm{g} / \mathrm{mL}$ OC-Exo group: 100).

\section{Analysis of cumulus cell proliferation rate}

We evaluated the cumulus cell proliferation degree using the vibrant MTT (3-(4,5-dimethyl-2-yl)-2,5-diphenyl tetrazolium bromide) assay. After $72 \mathrm{~h}$ of IVM, COCs were denuded with $0.1 \%$ hyaluronidase by pipetting and centrifuged at $1975 \mathrm{~g}$ for $2 \mathrm{~min}$ to collect the cumulus cells. Cumulus cells were cultured at a density of 10,000 cells per well in 96-well plates for $48 \mathrm{~h}$. The media were changed with fresh medium. The MTT solution was added to each well and incubated at $37^{\circ} \mathrm{C}$ for $4 \mathrm{~h}$. Next, the SDS-HCl solution was added and the plates were incubated at $37^{\circ} \mathrm{C}$ for $4 \mathrm{~h}$. Then, the absorbance was determined at $570 \mathrm{~nm}$. In total, 135 randomly selected canine COCs were used in three independent replicates for evaluating proliferation rate of cumulus cells experiment and 15 COCs were used per repeat (control group: 45, $25 \mu \mathrm{g} / \mathrm{mL}$ OC-Exo group: 45, $50 \mu \mathrm{g} / \mathrm{mL}$ OC-Exo group: 45).

\section{Total RNA extraction and cDNA synthesis}

Total RNA was extracted from (1) cumulus cells derived from each group of COCs treated with different concentrations of OC-Exo and (2) oocytes derived from each group of COCs treated with different concentrations of OC-Exo using Easyspin $^{\mathrm{TM}}$ Total RNA Extraction Kit (iNtRON Biotechnology Inc., Kyunggi, Korea). We assessed the concentration of isolated RNA by NanoDrop 2000 spectrophotometry (Thermo Fisher Scientific Inc), and cDNA was synthesized using amfiRivert II cDNA Synthesis Premix (GenDEPOT, TX, USA) with the manufacturer's instructions.

\section{Quantitative real-time PCR}

The primers for EGFR, PKA, TACE/ADAM17, MAPK1, MAPK3, MAPK14, PTGS2, HAS2, TNFAIP6, GDF9, BMP15, and $\beta$-actin genes were designed from sequences of canine genes obtained from NCBI; all primer sequences were standardized using a standard curve and are listed in Table 1. Real-time PCR was performed using an ABI 7300 Real-Time PCR System (Applied Biosystems) according to the manufacturer's instructions. The reaction mixture $(20 \mu \mathrm{L})$ comprised $2 \mu \mathrm{L}$ cDNA, $0.4 \mu \mathrm{L}$ forward and reverse primer, respectively, $10 \mu \mathrm{L}$ SYBR Green interaction dye (Takara Bio USA Inc.), and 7.2 $\mu$ L diethyl pyrocarbonate water and the reaction was carried out in a MicroAmp optical 96-well plate. The expression of each target gene was quantified relative to that of the internal control gene (betaactin) using the equation, $\mathrm{R}=2 \wedge(\Delta \mathrm{Ct}$ target gene in control group $-\Delta$ Ct control gene in control group $)-(\Delta \mathrm{Ct}$ target gene in treatment group $-\Delta \mathrm{Ct}$ control gene in treatment group). For real-time PCR, 175 randomly selected canine COCs were used in 12 technical independent replicates for evaluating gene expression levels (control group: 58, $25 \mu \mathrm{g} / \mathrm{mL}$ OC-Exo group: 62, $50 \mu \mathrm{g} / \mathrm{mL}$ OC-Exo group: 55).

Table 1 Sequence-specific primers used for quantification of differentially expressed transcripts for dogs.

\begin{tabular}{|c|c|c|c|c|}
\hline \multirow[b]{2}{*}{ Gene } & \multicolumn{2}{|c|}{ Primer sequences $\left(5^{\prime} \rightarrow 3^{\prime}\right)$} & \multirow[b]{2}{*}{ GenBank No } & \multirow[b]{2}{*}{ Product size $(b p)$} \\
\hline & Forward & Reverse & & \\
\hline$A C T B$ & GATCTGGCACCACACСТTCT & GGGGTGTTGAAAGTCTCGAA & XM_005621019.1 & 121 \\
\hline$E G F R$ & TTGCTGCACTGAGTTGATCC & CСGTCСТGСTTAGGAСТСТG & XM_022405164 & 194 \\
\hline$P K A$ & AGCAGGGCTACATTCAGGTG & TAGATCTGGATGGGCTGGTC & NM_001003032 & 214 \\
\hline TACE/ADAM17 & CTGTGGTGCAAAAGCAGAAA & СТGССТААТGССТСССААТА & XM_005630110 & 168 \\
\hline MAPK1 & ACAGTCTСТGСССТССАAGA & GGGTAGATCATCCAGCTCCA & NM_001252035 & 226 \\
\hline MAPK3 & TTGTGCTTGGAGCAGAAATG & CTGAGACGTTTGGGCTCTTC & NM_001110800.1 & 197 \\
\hline MAPK 14 & TTGGTCAGTGGGATGCATAA & AGTTCATCTTCGGCATCTGG & NM_001003206.1 & 191 \\
\hline PTGS2 & GCСTTACСCAGTTTGTGGAA & AGCCTAAAGCGTTTGCGATA & NM_001003354 & 163 \\
\hline HAS2 & ATCATCCAAAGCCTGTTTGC & TCATCTTCCGAGTTCCCATC & XM_539153.5 & 209 \\
\hline TNFAIP6 & TACAACCCACATGCAAAGGA & GGGTCATCCTCAAGGTCAAA & XM_533354.6 & 176 \\
\hline GDF9 & CAGAAGGGAGGTCTGTCTGC & CTTGTGCAGTTCCAAGCTGA & NM_0̄01168013 & 108 \\
\hline BMP15 & GACCСTTGGCGAATATAGCA & CGGTAAACCACAATGGCTCT & XM_003640274.2 & 118 \\
\hline
\end{tabular}

All primers showed an efficiency between 90 and $110 \%$ and a coefficient value $>0.9$. 


\section{Immunocytochemistry}

To assess the effect of OC-Exo on COCs, immunofluorescence staining was performed. The expression levels of $p$-EGFR and p-MAPK1/3 were analyzed in COCs and matured oocytes and the expression levels of GDF9 and BMP15 were assessed in matured oocytes from each group. Briefly, all samples were washed in PBS containing $0.2 \%$ polyvinyl alcohol and fixed with 4\% paraformaldehyde in PBS for $30 \mathrm{~min}$ at RT, then washed with PBS. Afterward, the samples were treated with $1 \%(\mathrm{v} / \mathrm{v})$ Triton $\mathrm{X}-100$ in PBS for $2 \mathrm{~h}$ and washed in PBS. Then the samples were incubated in $2 \%$ BSA in PBS for $4 \mathrm{~h}$. The samples were incubated with primary antibodies containing p-EGFR (1:200; ab32430; Abcam), p-MAPK1/3 (1:200; ab214362, Abcam), GDF9 (1:200; ab93892, Abcam), and BMP15 (1:200, PA5-34,401, Thermo Fisher Scientific) at $4{ }^{\circ} \mathrm{C}$ overnight. Then, the samples were washed in $2 \%$ BSA/PBS and incubated with goat anti-rabbit polyclonal antibody (1:200; ab6717, Abcam) as a secondary antibody for $3 \mathrm{~h}$ at RT. After washing in PBS, the samples were mounted on glass slides. The images of individual COCs and oocytes in each group were captured by a fluorescence microscope (Nikon Corp.). The fluorescence intensities of each protein were quantified by Image J (1.46. version) software (National Institutes of Health, USA). For immunostaining, 180 randomly selected COCs were used in four independent replicates for evaluating protein expression levels on each immunocytochemical analysis and three COCs were used per repeat (control group: 60, $25 \mu \mathrm{g} / \mathrm{mL}$ OC-Exo group: 60, $50 \mu \mathrm{g} / \mathrm{mL}$ OC-Exo group: 60).

\section{Statistical analysis}

Data were analyzed using one-way ANOVA followed by Tukey's multiple comparison test using GraphPad Prism 5.0. Values are shown as means \pm S.E.M. The significance level was
$P<0.05$, and at least three independent replications were performed in all experiments.

\section{Results}

\section{Characterization of oviductal exosomes}

The OC-Exo from estrus stage were previously identified (Lee et al. 2019). Briefly, the OC-Exo exhibited a spherical shape and the mean diameter was 150-200 $\mathrm{nm}$ in TEM examination (Fig. 1B). The NTA analysis revealed a single peak for 185-190 nm diameter particles at a concentration of $4.8-5.8 \times 10^{8}$ particles/ $\mathrm{mL}$ in the samples (Fig. 1C). Finally, it was confirmed by Western blot analysis that a specific exosomal marker, CD9, was present in OC-Exo (Fig. 1D). Moreover, in our recent study, CD81 and CD63 (exosomal specific markers) were observed in OC-Exo by Western blot and electrophoresis analysis (Lee et al. 2019). Also, calnexin, a non-exosome marker/protein associated with the endoplasmatic reticulum, was negative in OC-Exo and positive in cell lysates (Fig. 1D).

\section{Incorporation of oviductal exosomes by cumulus-oocyte complexes}

At first, exosomes labeled with PKH67 were observed within the cumulus cells after $24 \mathrm{~h}$ of culture during IVM but not in the cytoplasm of oocytes (Fig. 2C and D). After $48 \mathrm{~h}$, the incorporation of exosomes within the cumulus cell and the cytoplasm of oocyte was shown (Fig. 2E and F). In addition, considerable incorporation of labeled exosomes within the oocyte and all layers of the expanded cumulus cells was clearly visible $72 \mathrm{~h}$ after the start of IVM, as shown in Fig. 2G and $\mathrm{H}$.
Negative control
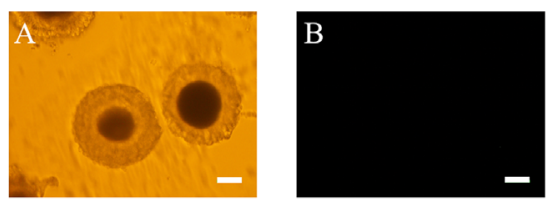

$48 \mathrm{~h}$
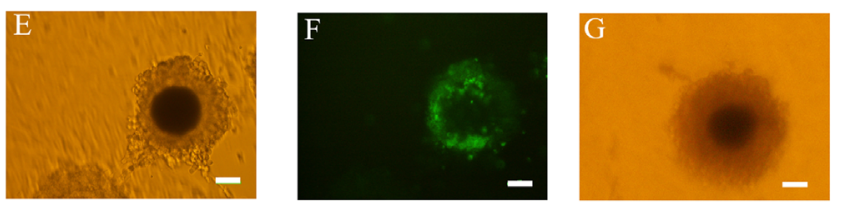

I

Incorporation of exosomes

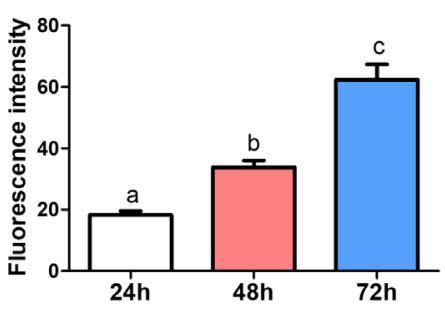

$72 \mathrm{~h}$

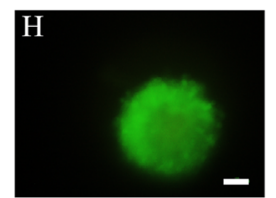

$24 \mathrm{~h}$

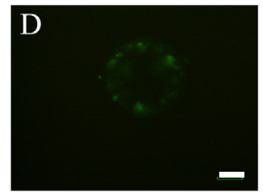

Figure 2 Incorporation of oviductal exosomes (OC-Exo) by oocytes. (A and B) Negative control for ensuring that nonspecific staining of cells from residual dye has not occurred. (C and D) Oocytes observed under visible light and labeled OC-Exo are present within the cumulus cells after $24 \mathrm{~h}$ of culture. (E and F) Oocytes observed under visible light and labeled OC-Exo are present within the cumulus cells and in the cytoplasm of oocytes after $48 \mathrm{~h}$ of IVM. (G and H) Oocytes observed under visible light and considerable incorporation of labeled OC-Exo are clearly visible within the cumulus cells and in the cytoplasm of oocytes after $72 \mathrm{~h}$ of IVM. (I) Measurement of PKH67 fluorescence intensity in each group after the culture period. Data are shown as the means \pm S.E.M. ${ }^{a, b, c}$ Within a column, values with different superscript letters are significantly different $(P<0.05)$. At least three replications were performed. 
To ensure that nonspecific staining of cells from residual PKH67 dye was not occurring, COCs were cultured with the supernatant from the last wash (negative control). As a result, no green fluorescence was observed in the negative control COCs (Fig. 2A and B). These results showed that oviductal exosomes labeled with PKH67 were incorporated into cumulus cells and oocytes in vitro.

\section{Effect of canine oviductal exosomes on cumulus expansion}

To determine whether OC-Exo have a physical effect on the COCs, the degree of cumulus expansion from each group was evaluated. After 24, 48, and $72 \mathrm{~h}$ of IVM, the degree of cumulus expansion was analyzed in each group of COCs. After $24 \mathrm{~h}$ of IVM, there was a significantly increased proportion of small expansion degree in $25 \mu \mathrm{g} / \mathrm{mL}$ OC-Exo group compared with the other groups $(P<0.05)$ (Fig. $3 \mathrm{~A}$ and $\mathrm{B})$. Furthermore, the expanded degree of COCs was significantly increased in $25 \mu \mathrm{g} / \mathrm{mL}$ OC-Exo-treated group compared to the other groups within $48 \mathrm{~h}$ of IVM $(P<0.05)$ (Fig. 3A and B). Finally, the $25 \mu \mathrm{g} / \mathrm{mL}$ OC-Exo group exhibited a significant increase in the rate of expanded COCs compared to the other groups and the proportion of small expansion degree in $25 \mu \mathrm{g} / \mathrm{mL}$ OC-Exo group was also significantly increased compared to the control $(P<0.05)$ (Fig. $3 \mathrm{~A}$ and B). Assessment of the degree of cumulus expansion confirmed that $25 \mu \mathrm{g} / \mathrm{mL}$ OC-Exo-treated group showed a significant increase in the proportion of COCs exhibiting cumulus expansion $(P<0.05)$ (Fig. 3A and B).

\section{Effect of canine oviductal exosomes on proliferation rate of cumulus cells}

As a result, a significant increase in cumulus cell proliferation in exosome-treated group in $570 \mathrm{~nm}$ absorbance was observed. Specifically, significant increased rate of cumulus cell proliferation was observed in 25 and $50 \mu \mathrm{g} / \mathrm{mL}$ oviductal exosome treated group (Absorbance: $0.632 \pm 0.006$ and $0.606 \pm 0.008$, respectively, $P<0.05)$ when compared with the control group (Absorbance: $0.561 \pm 0.010, P<0.05$ ) (Fig. 4A) There were no significant differences in cumulus cell proliferation rate among oviductal exosome treated groups (Fig. 4A).

\section{Effect of canine oviductal exosomes on in vitro maturation of canine oocytes}

Based on the extrusion of the first polar body (Metaphase II) from oocytes in each group (Fig. 4D), we analyzed the effects of oviductal exosomes on in vitro maturation of canine oocytes. Canine oocytes with normal morphology were selected for IVM (Fig. 4B). The nuclear maturation rate of oocytes in the $25 \mu \mathrm{g} / \mathrm{mL}$ oviductal exosometreated group $(22.5 \pm 1.7 \%, P<0.05)$ were significantly higher than those of control and $50 \mu \mathrm{g} / \mathrm{mL}$ treated groups $(9.0 \pm 3.3$ and $11.2 \pm 3.2 \%$, respectively, $P<0.05)$ (Fig. 4C). There were no significant differences in the number of degenerated and immature oocytes among groups.

\section{Relative expression levels of genes relevant to EGFR signaling in cumulus cells and oocytes}

The relative mRNA transcript levels of the EGFR/MAPK pathway were analyzed in canine cumulus cells and oocytes from COCs after IVM (Fig. 5). The upstream genes of EGFR pathway, including EGFR and $P K A$, were significantly increased in the 25 and $50 \mu \mathrm{g} / \mathrm{mL}$ OC-Exo-treated group compared with the control group $(P<0.05)$ (Fig. 5A and B), and other upstream EGFR signaling genes, TACE/ADAM17, were significantly increased in the $25 \mu \mathrm{g} / \mathrm{mL}$ exosome group compared with the other groups $(P<0.05)$ (Fig. 5C). Furthermore,
A

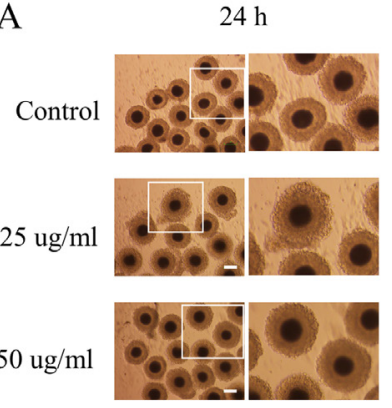

B

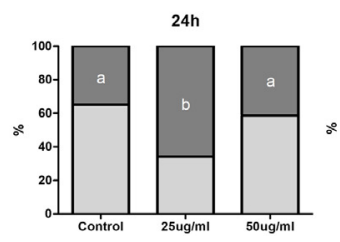

$48 \mathrm{~h}$
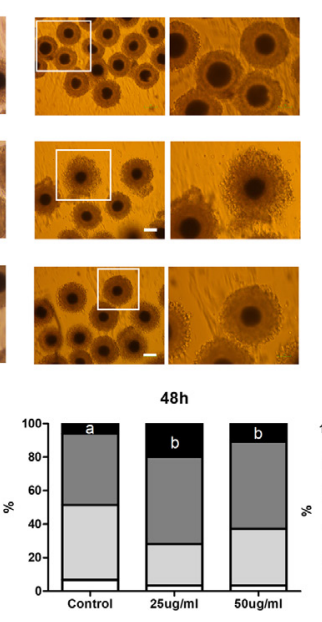
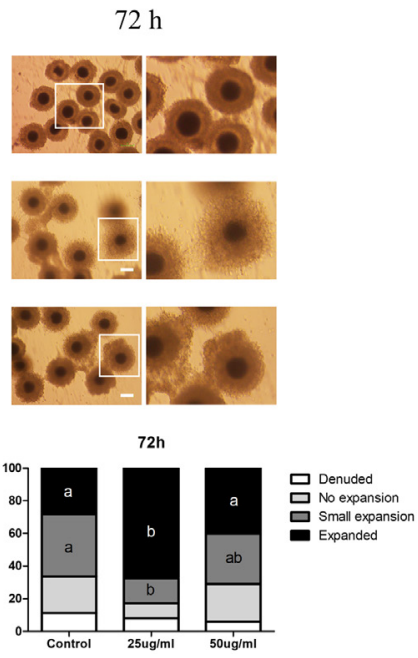

Figure 3 Effect of canine oviductal exosomes (OC-Exo) on cumulus expansion, proliferation rate of cumulus cells and nuclear maturation rate of oocytes after IVM. The cumulus expansion scoring system was as follows: no expansion, all layers of cumulus cells were tightly attached to the oocyte; small expansion, the two outer layers showed a little halo around the COCs; expanded, more than three layers of cumulus cells were expanded around the oocyte; and denuded, without any cumulus cells attached. (A and B) The degree of cumulus expansion at 24, 48 and $72 \mathrm{~h}$ of IVM in control, 25 , and $50 \mu \mathrm{g} / \mathrm{mL}$ OC-Exotreated groups with magnified images of the boxes identified in (A). Bar: $100 \mu \mathrm{m}$. Data are shown as the means \pm S.E.M. ${ }^{\text {a,b }}$ Within a column, values with different superscript letters are significantly different $(P<0.05)$. 
A

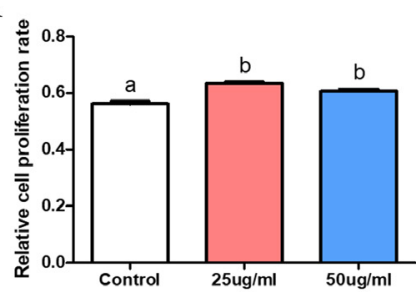

B

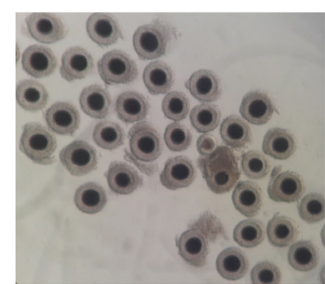

D

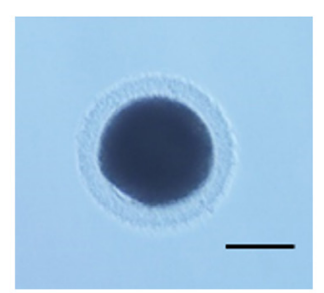

\begin{tabular}{cc}
\hline Group & Relative cell proliferation rate \\
\hline Control & $0.561 \pm 0.010^{\mathrm{a}}$ \\
$25 \mathrm{ug} / \mathrm{ml}$ & $0.632 \pm 0.006^{\mathrm{b}}$ \\
$50 \mathrm{ug} / \mathrm{ml}$ & $0.606 \pm 0.008^{\mathrm{b}}$ \\
\hline
\end{tabular}

$\mathrm{C}$

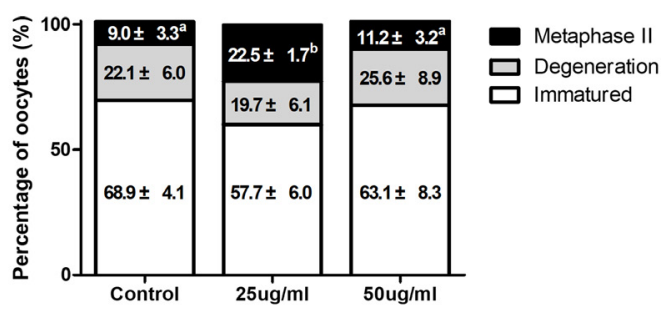

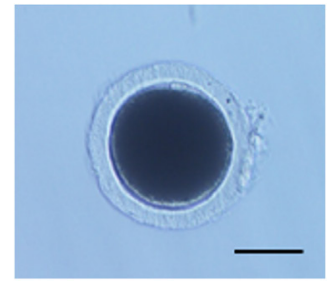

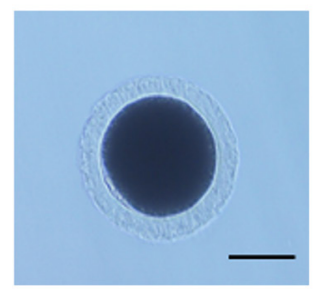

Figure 4 (A) Effect of oviductal exosomes (OC-Exo) on the proliferation rate of cumulus cells in control, 25, and $50 \mu \mathrm{g} / \mathrm{mL}$ OC-Exotreated groups. (B) Morphology of canine oocytes selected for IVM and (C) effect of different concentration of oviductal exosomes (OC-Exo) on nuclear maturation of canine oocytes. Metaphase II indicates oocyte maturation. (D) First polar body extrusion in control, 25, and $50 \mu \mathrm{g} / \mathrm{mL}$ exosome-treated group. Data are shown as the means \pm S.E.M. a,b Within a column, values with different superscript letters are significantly different $(P$ $<0.05)$. Bar: $50 \mu \mathrm{m}$.

Figure 5 The mRNA expression levels of EGFR signaling pathway-related genes in cumulus cells and oocyte-maturation-related genes in oocytes derived from cumulus-oocyte complexes in control, 25 , and $50 \mu \mathrm{g} / \mathrm{mL}$ OC-Exo-treated groups. (A, B and C) Expression of upstream genes related with EGFR/MAPK signaling pathway in cumulus cells derived from each group. (D, E and F) Expression of downstream genes related with EGFR/MAPK signaling pathway in cumulus cells derived from each group. $(\mathrm{G}, \mathrm{H}$ and $\mathrm{I})$ Expression of downstream genes related with cumulus EGFR/MAPK signaling pathway and cumulus expansion in cumulus cells derived from each group. ( $\mathrm{a}$ and $\mathrm{K}$ ) Expression of genes related with oocyte maturation in oocyte derived from each group. EGFR, epidermal growth factor receptor; $\mathrm{PKA}$, protein kinase $\mathrm{A}$; TACE/ADAM17, tumor necrosis factor alpha-converting enzyme and a disintegrin and metalloprotease 17; MAPK1, mitogenactivated protein kinase 1 ; MAPK3, mitogenactivated protein kinase 3; MAPK14, mitogen-activated protein kinase 14; PTGS2, prostaglandin-endoperoxide synthase 2; HAS2, hyaluronan synthase 2; TNFAIP6, tumor necrosis factor alpha induced protein 6; GDF9, growth differentiation factor 9; BMP15, bone morphogenetic protein 15. Data are shown as the means \pm S.E.M. ${ }^{a, b, c}$ Within a column, values with different superscript letters are significantly different $(P<0.05)$. At least six replications were performed. 
the downstream genes of the EGFR signaling pathway, such as MAPK1, MAPK3, and MAPK14, were also significantly up-regulated in OC-Exo-treated groups compared to those of the control $(P<0.05)$ (Fig. 5D, $\mathrm{E}$ and $\mathrm{F})$. Particularly, the expression level of MAPK3 was significantly up-regulated in $25 \mu \mathrm{g} / \mathrm{mL}$ OC-Exo group compared to those of $50 \mu \mathrm{g} / \mathrm{mL}$ group $(P<0.05)$ (Fig. 5E). Moreover, $25 \mu \mathrm{g} / \mathrm{mL}$ exosome group showed a significant increase in the cumulus expansion-related genes (PTGS2 and TNFAIP6) compared with the control group ( $P<0.05)$ (Fig. 5G and I). In addition, the $25 \mu \mathrm{g} / \mathrm{mL}$ exosome group showed a significant increase in the mRNA expression of the oocyte-maturation-related genes such as GDF9 and BMP15 compared to the other groups $(P<0.05)$ (Fig. 5J and $\mathrm{K}$ ).

\section{Relative fluorescence intensity of p-EGFR, p-MAPK1/3, GDF9, and BMP15 in canine cumulus-oocyte complexes and oocytes}

For evaluating the effect of OC-Exo on the relative protein levels of the EGFR/MAPK signaling pathway, immunocytochemistry analysis was performed in each group of COCs and oocytes. The fluorescence intensity of p-EGFR in COCs in the 25 and $50 \mu \mathrm{g} / \mathrm{mL}$ OC-Exo-treated group was significantly increased compared with those of control $(P<0.05)$ (Fig. 6A and B). Moreover, the protein expression level of p-MAPK $1 / 3$ in COCs was significantly up-regulated in exosometreated groups; the $25 \mu \mathrm{g} / \mathrm{mL}$ OC-Exo group showed markedly increased $p$-MAPK $1 / 3$ levels compared with those of $50 \mu \mathrm{g} / \mathrm{mL}$ OC-Exo group $(P<0.05)$ (Fig. 7A and $B$ ). The $p$-EGFR and $p$-MAPK $1 / 3$ were also detected within the oocyte (Fig. 8A), and their expression level was significantly up-regulated in $25 \mu \mathrm{g} / \mathrm{mL}$ OC-Exo-treated group compared to those of other groups $(P<0.05)$ (Fig. 8A and B). Moreover, a significant increase in the fluorescence intensities of GDF9 and BMP15 was observed in $25 \mu \mathrm{g} / \mathrm{mL}$ OC-Exo group compared to the control $(P<0.05)$ (Fig. 8A and B).

\section{Discussion}

In the present study, for the first time, we demonstrated the effect of oviductal exosomes on canine oocyte maturation during IVM and the gene/protein expression levels relevant to EGFR/MAPK pathway. Based on our result, we propose that canine oviductal exosomes can be incorporated into COCs and have beneficial effects on canine oocyte development and the physiological function of cumulus cells as well as enhance the gene/ protein expression related with EGFR/MAPK pathway.

Till date, the potential physiological characteristics of oviduct cells have been investigated in the field of reproduction (No et al. 2018, Budna-Tukan et al. 2019, Ferraz et al. 2019) because serial reproductive processes, including gamete maturation, fertilization, and embryo development, occur within the oviductal canal. The maternal tract, including oviductal canal and uterus, has been shown to regulate gamete and embryo interaction by altering transcript abundance (AI-Dossary \& Martin-Deleon 2016, Burns et al. 2016, Di Pietro 2016). In particular, oviduct in canine species has peculiar properties that enhance oocyte development and prolong the survival of the germ cells (Luvoni et al. 2005). In our previous study, the co-culture of oocytes with canine oviduct cells had markedly improved the oocyte and embryo development by stimulating the EGFR signaling pathway (Lee et al. 2019). However, the indirect positive effects of oviduct cells on the improvement of
A
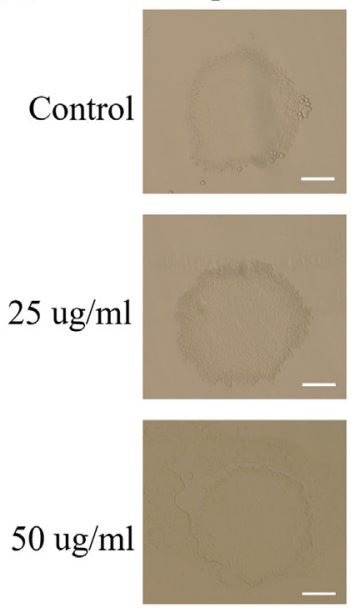
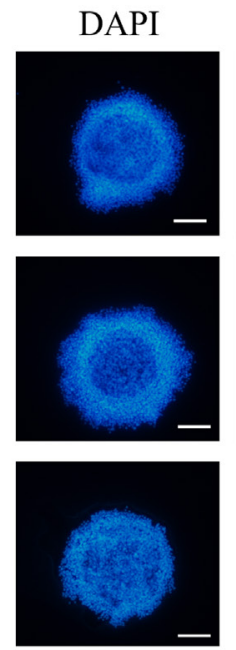
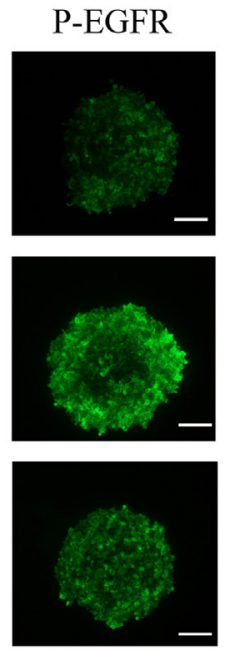
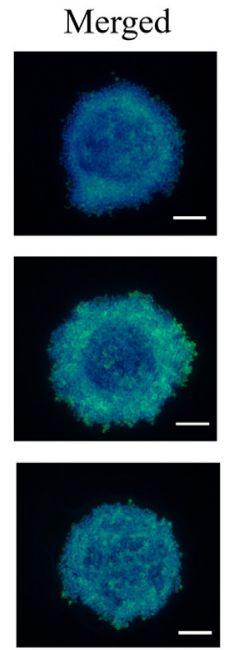
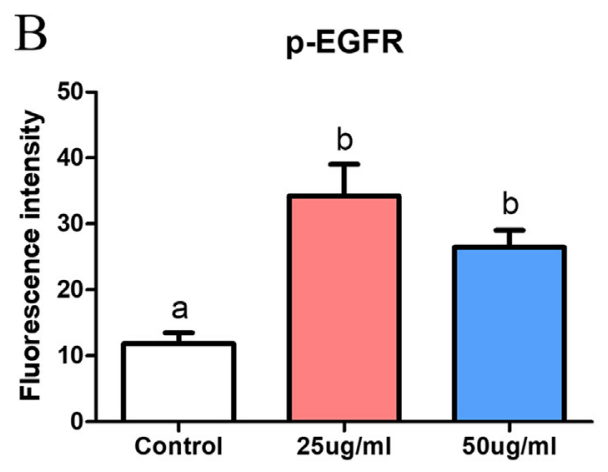

Figure 6 Association between oviductal exosomes (OC-Exo) and cumulus-oocyte complexes (COCs) in the EGFR signaling pathway. (A) Immunocytochemical analysis of phospho-EGFR (p-EGFR, green) in COCs and their nuclear staining (DAPI, blue) in control, 25 , and 50 $\mu$ g/mL OC-Exo-treated groups. (B) The fluorescence intensity of p-EGFR in each group of COCs. Data are shown as the means \pm S.E.M. a,bWithin a column, values with different superscript letters are significantly different $(P<0.05)$. At least five replications were performed. Bar: $50 \mu \mathrm{m}$. 
A

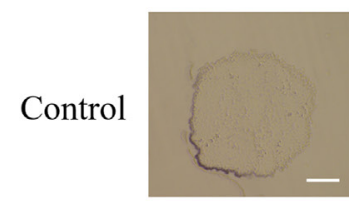

$25 \mathrm{ug} / \mathrm{ml}$

$50 \mathrm{ug} / \mathrm{ml}$
DAPI
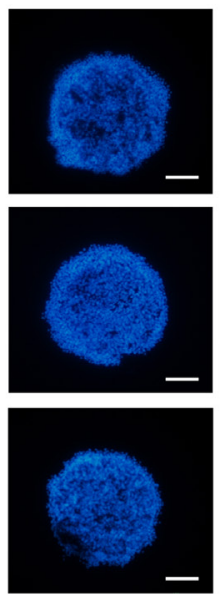

p-MAPK1/3
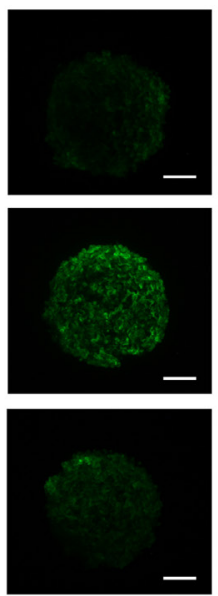

Merged

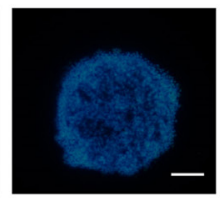

B

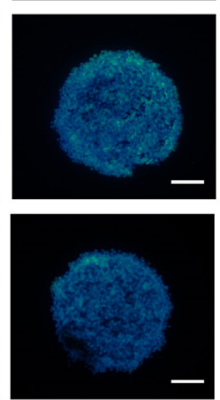

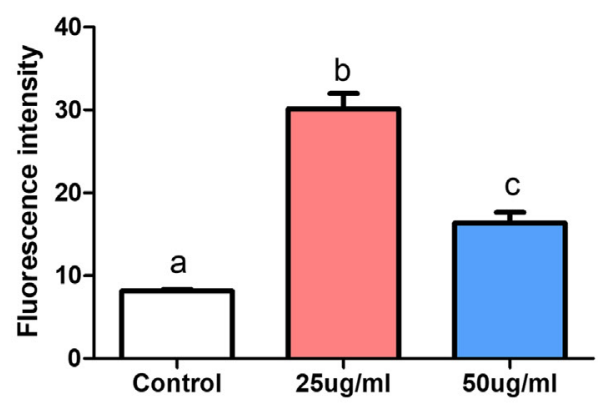

Figure 7 (A) Effect of oviductal exosomes (OC-Exo) on the expression of phospho-MAPK1/3 (p-MAPK1/3, green) protein in cumulus-oocyte complexes (COCs) and their nuclear staining (DAPI, blue) in control, 25, and $50 \mu \mathrm{g} / \mathrm{mL}$ OC-Exo-treated groups. (B) The fluorescence intensity for

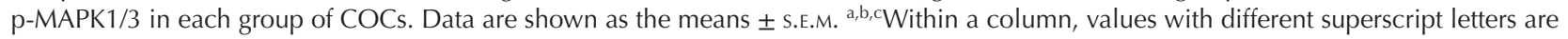
significantly different $(P<0.05)$. At least five replications were performed. Bar: $50 \mu \mathrm{m}$.

oocyte competence are yet to be established. As in vivo immature canine oocytes indirectly interact with oviduct for maturation, it is conceivable that the secretome of oviduct cells would play a key role in canine oocyte development. Among numerous secretomes, exosomes have been considered as the important mediators in cell communication through the transfer of their molecular cargoes (protein, mRNA, miRNA) (Hoshino et al. 2015, Zhang et al. 2015). In our recent study, we demonstrated the relationship between canine oviduct cell-derived exosomes and cumulus cells in the EGFR/MAPK pathway and showed that oviductal exosomes improve the physiological state of cumulus cells as well as gene/ protein expression levels related with EGFR/MAPK signaling in cumulus cells (Lee et al. 2019). However, to the best of our knowledge, still, none of the research has provided the effect of exosomes on canine oocyte development at a molecular fashion. Therefore, in the present study, we investigated their effects on in vitro maturation of oocytes and cumulus expansion during IVM and the expression of genes/proteins related to EGFR/MAPK pathway.

To investigate whether canine oocytes could take up OC-Exo, PKH67-labelled OC-Exo were co-incubated with oocytes during IVM. According to our results, the intensity of labeled OC-Exo appeared in the surrounding
A

Control
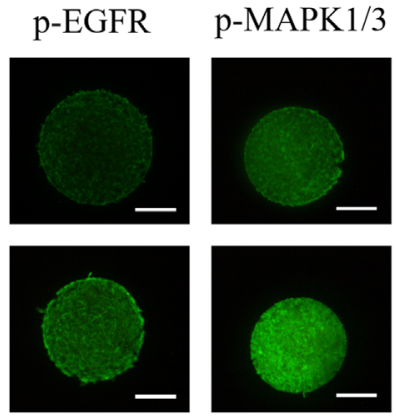

$50 \mathrm{ug} / \mathrm{ml}$
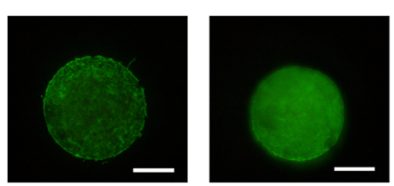

GDF9
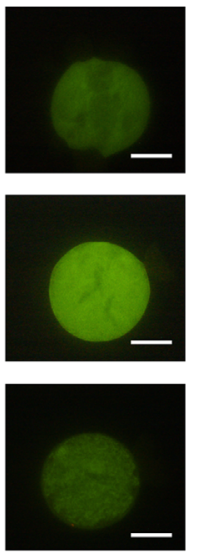

BMP15
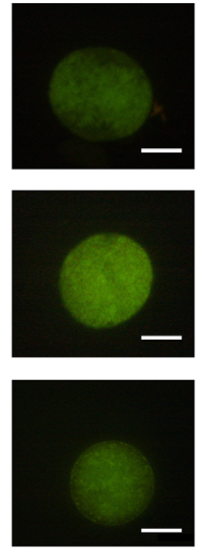

B
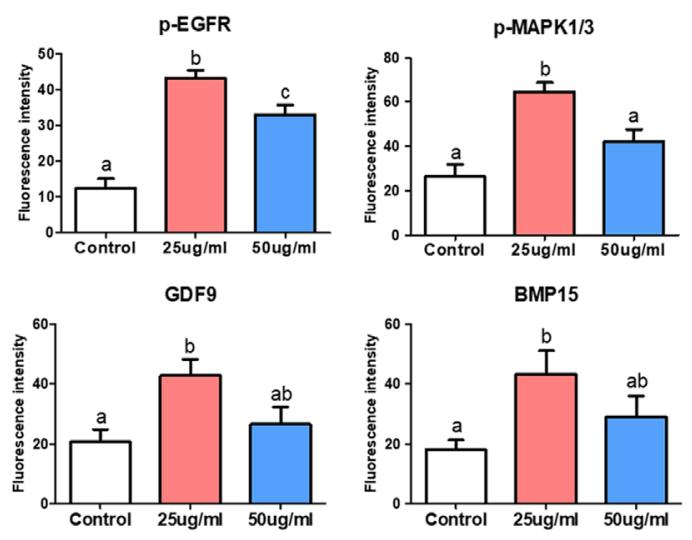

Figure 8 The effect of oviductal exosomes (OC-Exo) on protein expression of the EGFR/MAPK signaling pathway and oocyte maturation in oocytes derived from control, 25, and $50 \mu \mathrm{g} / \mathrm{mL}$ OC-Exo-treated groups. (A) Immunocytochemical analysis of phospho-EGFR (p-EGFR), phospho-MAPK1/3 (p-MAPK1/3), GDF9, and BMP15 in oocytes derived from control, 25 and $50 \mu \mathrm{g} / \mathrm{mL}$ OC-Exo-treated groups. (B) The

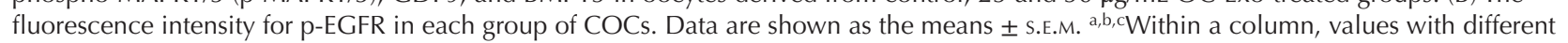
superscript letters are significantly different $(P<0.05)$. At least five replications were performed. Bar: $50 \mu \mathrm{m}$. 
cumulus cells after $24 \mathrm{~h}$ of IVM and the OC-Exo was gradually increased within the cytoplasm of oocytes after $48 \mathrm{~h}$ and $72 \mathrm{~h}$ of IVM. Thus, we demonstrated that cumulus cells play a role in the paracrine mechanism as a messenger between oocytes and OC-Exo, considering that cumulus cells are incorporated within exosomes before oocyte uptake during IVM. As oocyte maturation in other mammals, such as cow, horse, and pig, occurs in the ovarian follicle in vivo, recent studies focused on the relationship between ovarian follicular EVs/ exosomes and gamete maturation (Hung et al. 2015, Rodrigues et al. 2019). Meanwhile, the canine oviduct cells have potential physiological characteristics for oocyte maturation compared with other mammals. It has been identified that oviduct-derived EVs cargo has a set of proteins with essential roles between gamete and oviduct interactions (Machtinger et al. 2016, Alminana et al. 2017). In the present study, we demonstrated for the first time that OC-Exo could enhance the COCs development and markedly increase the maturation rate in canine COCs compared with the other groups. Therefore, the results support our hypothesis that oviductal exosomes play potential roles in the release of various proteins into the oviduct milieu, which are incorporated into the oocytes, allowing successful oocyte maturation.

In previous studies, EGF-like peptides influenced cumulus cell expansion as well as gene expression in pig and rat (Sekiguchi et al. 2004, Prochazka et al. 2012). Also, it has been proved that EGF can enhance oocyte maturation factor including MAPK, p34 ${ }^{\text {cdc2 }}$ and cyclin B (Pereira et al. 2019) and that it exerted a positive effect on the progression of MII phase of oocyte in dog (Hatoya et al. 2009, Song et al. 2011). In addition, another report implicated exosomes in the gene expression of cultured granulosa cells (da Silveira et al. 2014), which suggested that exposure to the exosomes is closely related with the gene expression change. In the present study, we showed that OC-Exo supported cumulus expansion and genes associated with cumulus expansion and oocyte maturation. Therefore, we speculated that OC-Exo could mimic the physiological changes in canine COCs, which can be seen in intact canine COCs undergoing development in vivo.

Previous research suggested that when exosomes imparted their genetic material to recipient cells by releasing vesicles, they possessed an EGFR ligand, AREG (Higginbotham et al. 2011, Taverna et al. 2017). In addition, based on our previous research on the physiological properties of OC-Exo on EGFR/MAPK pathway (Lee et al. 2019), it is possible that OC-Exo improved the gene expression levels of canine COCs via the EGFR/MAPK signaling pathway.

Early evidence substantiates that the participation of the EGFR signaling pathway in oocyte maturation and cumulus expansion originated from in vitro studies. A research demonstrated that the EGFR signaling pathway in COCs is critical for oocyte meiotic resumption as well as provided evidence of how this network influences the oocyte developmental capacity (Park et al. 2004). To activate the EGFR signaling pathway, production of EGF-like peptides is necessary and these proteins stimulate protein kinase A (PKA) in follicular cells, which is required for cumulus expansion (Fan et al. 2010, Prochazka et al. 2012). In our recent studies, we showed that oviduct cells stimulated with progesterone successfully increased the production of AREG (Lee et al. 2019) and that the exosomes derived from oviduct cells activated the EGFR/MAPK signaling pathway in canine cumulus cells in vitro (Lee et al. 2019). The released EGF-like peptides are tethered to follicular cells and then cleaved at the ectodomain by the TACE/ADAM17 (Dong et al. 1999, Sahin et al. 2004), which is required for the activation of EGFR and its downstream targets in cumulus cells. The EGFR signaling activation promotes the MAPK $1 / 3$ pathway in cumulus cells (Oda et al. 2005), which is fundamental in the mediation of serial gene expression related to oocyte maturation (Shimada et al. 2016). The gene transcription of EGFR-MAPK $1 / 3$ is responsible for the MAPK14 (p38MAPK) induction in cumulus cells, which up-regulates and maintains the overall EGF network for inducing oocyte maturation and cumulus expansion as key downstream effectors (Park et al. 2004, Downs \& Chen 2008). Thus, it is evident that once the EGFR/MAPK signaling is activated, the downstream pathway related to cumulus expansion is enhanced (Yamashita et al. 2011). Therefore, in the current study, the expression levels of genes relevant to EGFR/MAPK pathway in matured oocytes and cumulus cells were measured to ascertain whether characteristics of canine COCs were changed by exosomes derived from oviduct cells. Based on our results, we suggested that exposure of OC-Exo to oocytes during IVM significantly increased expression levels of the upstream and downstream EGFR/MAPK pathway-related genes in the resultant COCs. Taken together, our results support the hypothesis that OC-Exo would act on canine COCs during oocyte maturation to improve the competence of oocytes and enhance the gene expression levels via EGFR/MAPK pathway.

For the maturation of oocytes, not only EGFR/MAPK signaling activation in cumulus cells is required but also the cues of oocytes are essential to promote oocyte development (Diaz et al. 2006, 2007). The GDF9 and BMP15 have been described as important factors for oocyte maturation (Dong et al. 1996, Galloway et al. 2002). A recent study suggested that the participation of oocyte-secreted factors, GDF9 and BMP15, is required for obtaining an AREG-responsive state in porcine COCs (Sugimura et al. 2015). A study proved that mouse oocytes are closely involved in the expression of EGFR in cumulus cells via GDF9 and BMP15 activation (Su et al. 2010) and another study suggested that a crosstalk between EGFR-MAPK1/3 and GDF9/BMP15 existed 


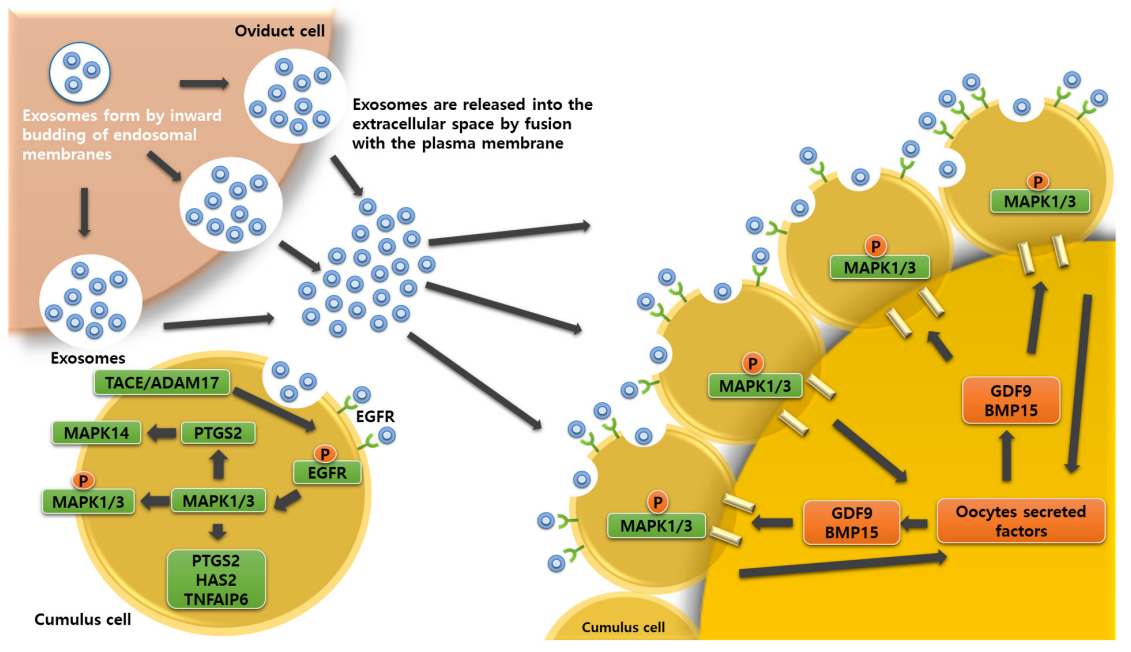

Figure 9 A schematic illustration of the relation between canine oviductal exosomes and cumulus-oocyte complexes via the EGFR/ MAPK signaling pathway. Exosomes form by inward budding of the endosomal membranes of oviduct cells. After the exosomes are released into the extracellular space by fusion with the plasma membrane of oviduct cells, their interaction with cumulus cells induces rapid activation and internalization of EGFR and endocytosis. The alteration in EGFR on cumulus cells via oviductal exosomes significantly activates the EGFR/MAPK signaling pathway in cumulus cells, and it would subsequently improve oocyte maturation.

for oocyte maturation (Sasseville et al. 2010). Likewise, we proposed that the increased transcript levels of the EGFR pathway induced by OC-Exo might activate the response to oocyte-secreted factors. Based on our results, we suggested that an up-regulated expression of genes in cumulus cells and oocytes via OC-Exo markedly improved the protein levels of GDF9, BMP15, p-EGFR, and p-MAPK $1 / 3$ in oocytes and p-EGFR and p-MAPK $1 / 3$ in cumulus cells, which substantiate that signals derived from exosomes can reach beyond the oocyte and modulate their gene expression during IVM of oocytes. Such insights might represent a potential IVM system that mimics the signaling events occurring in vivo.

In conclusion, for the first time, we have demonstrated the effect of oviductal exosomes on in vitro maturation of canine oocytes and the alteration of gene/protein levels relevant to the EGFR/MAPK signaling within COCs (Fig. 9). The alteration of EGFR on cumulus cells via oviductal exosomes significantly activated the EGFR/MAPK signaling pathway in cumulus cells and subsequently improved oocyte maturation, which would clarify the role of oviductal exosomes on oocyte development, fertilization, as well as embryo implantation in the field of reproductive biology in the future.

\section{Declaration of interest}

The authors declare that there is no conflict of interest that could be perceived as prejudicing the impartiality of the research reported.

\section{Funding}

This research was supported by the global PhD Fellowship Program through NRF funded by the Ministry of Education (NRF-20142A1021187).

\section{Author contribution statement}

S H L conceived the study, carried out the experiments, then performed the statistical analysis and drafted the manuscript. $\mathrm{H} \mathrm{J} \mathrm{O}$ and $\mathrm{B} C \mathrm{C}$ assisted with designing the experiment and statistical analysis of the data. M J K assisted with implementation of the experiments and manuscript drafting. All co-authors revised the manuscript. B C L supervised the research and supplied the funding. All authors read, revised, and approved the final manuscript.

\section{Acknowledgements}

The authors would like to acknowledge the Research Institute for Veterinary Science and the BK21 plus program who provided insight and expertise that greatly assisted the research.

\section{References}

Al-Dossary AA \& Martin-Deleon PA 2016 Role of exosomes in the reproductive tract oviductosomes mediate interactions of oviductal secretion with gametes/early embryo. Frontiers in Bioscience $\mathbf{2 1}$ 1278-1285. (https://doi.org/10.2741/4456)

Alminana C, Corbin E, Tsikis G, Alcantara-Neto AS, Labas V, Reynaud K, Galio L, Uzbekov R, Garanina AS, Druart X et al. 2017 Oviduct extracellular vesicles protein content and their role during oviductembryo cross-talk. Reproduction 154 153-168. (https://doi.org/10.1530/ REP-17-0054)

Bogliolo L, Zedda MT, Ledda S, Leoni G, Naitana S \& Pau S 2002 Influence of co-culture with oviductal epithelial cells on in vitro maturation of canine oocytes. Reproduction, Nutrition, Development 42 265-273. (https://doi.org/10.1051/rnd:2002024)

Budna-Tukan J, Swiatly-Blaszkiewicz A, Celichowski P, Kaluzna S, Konwerska A, Sujka-Kordowska P, Jankowski M, Kulus M, Jeseta $M$, Piotrowska-Kempisty H et al. 2019 'Biological adhesion' is a significantly regulated molecular process during long-term primary in vitro culture of oviductal epithelial cells (Oecs): a transcriptomic and proteomic study. International Journal of Molecular Sciences 203387. (https://doi.org/10.3390/ijms20143387)

Burns GW, Brooks KE \& Spencer TE 2016 Extracellular vesicles originate from the conceptus and uterus during early pregnancy in sheep. Biology of Reproduction 94 56. (https://doi.org/10.1095/ biolreprod.115.134973) 
da Silveira JC, Carnevale EM, Winger QA \& Bouma GJ 2014 Regulation of ACVR1 and ID2 by cell-secreted exosomes during follicle maturation in the mare. Reproductive Biology and Endocrinology 12 44. (https://doi. org/10.1186/1477-7827-12-44)

Di Pietro C 2016 Exosome-mediated communication in the ovarian follicle. Journal of Assisted Reproduction and Genetics 33 303-311. (https://doi.org/10.1007/s10815-016-0657-9)

Diaz FJ, O'Brien MJ, Wigglesworth K \& Eppig JJ 2006 The preantral granulosa cell to cumulus cell transition in the mouse ovary: development of competence to undergo expansion. Developmental Biology 299 91-104. (https://doi.org/10.1016/j.ydbio.2006.07.012)

Diaz FJ, Wigglesworth K \& Eppig JJ 2007 Oocytes are required for the preantral granulosa cell to cumulus cell transition in mice. Developmental Biology 305 300-311. (https://doi.org/10.1016/j.ydbio.2007.02.019)

Dong J, Albertini DF, Nishimori K, Kumar TR, Lu N \& Matzuk MM 1996 Growth differentiation factor-9 is required during early ovarian folliculogenesis. Nature 383 531-535. (https://doi. org/10.1038/383531a0)

Dong J, Opresko LK, Dempsey PJ, Lauffenburger DA, Coffey RJ \& Wiley HS 1999 Metalloprotease-mediated ligand release regulates autocrine signaling through the epidermal growth factor receptor. PNAS 96 6235-6240. (https://doi.org/10.1073/pnas.96.11.6235)

Downs SM \& Chen J 2008 EGF-like peptides mediate FSH-induced maturation of cumulus cell-enclosed mouse oocytes. Molecular Reproduction and Development 75 105-114. (https://doi.org/10.1002/ mrd.20781)

El Andaloussi S, Lakhal S, Mager I \& Wood MJ 2013 Exosomes for targeted siRNA delivery across biological barriers. Advanced Drug Delivery Reviews 65 391-397. (https://doi.org/10.1016/j.addr.2012.08.008)

Fan HY, O'Connor A, Shitanaka M, Shimada M, Liu Z \& Richards JS 2010 Beta-catenin (CTNNB1) promotes preovulatory follicular development but represses LH-mediated ovulation and luteinization. Molecular Endocrinology 24 1529-1542. (https://doi.org/10.1210/me.2010-0141)

Ferraz MAMM, Carothers A, Dahal R, Noonan MJ \& Songsasen N 2019 Oviductal extracellular vesicles interact with the spermatozoon's head and mid-piece and improves its motility and fertilizing ability in the domestic cat. Scientific Reports 9 9484. (https://doi.org/10.1038/ s41598-019-45857-x)

Galloway SM, Gregan SM, Wilson T, McNatty KP, Juengel JL, Ritvos O \& Davis GH 2002 Bmp15 mutations and ovarian function. Molecular and Cellular Endocrinology 191 15-18. (https://doi.org/10.1016/s03037207(02)00047-3)

Haney MJ, Klyachko NL, Zhao Y, Gupta R, Plotnikova EG, He Z, Patel T, Piroyan A, Sokolsky M, Kabanov AV et al. 2015 Exosomes as drug delivery vehicles for Parkinson's disease therapy. Journal of Controlled Release 207 18-30. (https://doi.org/10.1016/j.jconrel.2015.03.033)

Hatoya S, Sugiyama Y, Nishida H, Okuno T, Torii R, Sugiura K, Kida K, Kawate N, Tamada H \& Inaba T 2009 Canine oocyte maturation in culture: significance of estrogen and EGF receptor gene expression in cumulus cells. Theriogenology 71 560-567. (https://doi.org/10.1016/j. theriogenology.2008.08.013)

Hewitt DA \& England GC 1998 The effect of oocyte size and bitch age upon oocyte nuclear maturation in vitro. Theriogenology 49 957-966. (https://doi.org/10.1016/s0093-691x(98)00044-2)

Higginbotham JN, Demory Beckler M, Gephart JD, Franklin JL, Bogatcheva G, Kremers GJ, Piston DW, Ayers GD, McConnell RE, Tyska MJ et al. 2011 Amphiregulin exosomes increase cancer cell invasion. Current Biology 21 779-786. (https://doi.org/10.1016/j. cub.2011.03.043)

Holst PA \& Phemister RD 1971 The prenatal development of the dog: preimplantation events. Biology of Reproduction 5 194-206. (https:// doi.org/10.1093/biolreprod/5.2.194)

Hoshino A, Costa-Silva B, Shen TL, Rodrigues G, Hashimoto A, Tesic Mark M, Molina H, Kohsaka S, Di Giannatale A, Ceder S et al. 2015 Tumour exosome integrins determine organotropic metastasis. Nature 527 329-335. (https://doi.org/10.1038/nature15756)

Hung WT, Hong X, Christenson LK \& McGinnis LK 2015 Extracellular vesicles from bovine follicular fluid support cumulus expansion. Biology of Reproduction 93 117. (https://doi.org/10.1095/ biolreprod.115.132977)

Kosaka N, Iguchi H, Yoshioka Y, Takeshita F, Matsuki Y \& Ochiya T 2010 Secretory mechanisms and intercellular transfer of microRNAs in living cells. Journal of Biological Chemistry 285 17442-17452. (https://doi. org/10.1074/jbc.M110.107821)

Lee BC, Kim MK, Jang G, Oh HJ, Yuda F, Kim HJ, Hossein MS, Kim JJ, Kang SK, Schatten G et al. 2005 Dogs cloned from adult somatic cells. Nature 436 641. (https://doi.org/10.1038/436641a)

Lee SH, Oh HJ, Kim MJ, Kim GA, Choi YB, Jo YK, Setyawan EMN \& Lee BC 2017 Oocyte maturation-related gene expression in the canine oviduct, cumulus cells, and oocytes and effect of co-culture with oviduct cells on in vitro maturation of oocytes. Journal of Assisted Reproduction and Genetics 34 929-938. (https://doi.org/10.1007/s10815-017-0910-x)

Lee SH, Oh HJ, Kim MJ, Kim GA, Choi YB, Jo YK, Setyawan EMN \& Lee BC 2018 Effect of co-culture canine cumulus and oviduct cells with porcine oocytes during maturation and subsequent embryo development of parthenotes in vitro. Theriogenology 106 108-116. (https://doi. org/10.1016/j.theriogenology.2017.09.015)

Lee SH, Oh HJ, Kim MJ, Setyawan EMN \& Lee BC 2019 Interaction of the EGFR signaling pathway with porcine cumulus oocyte complexes and oviduct cells in a coculture system. Journal of Cellular Physiology 234 4030-4043. (https://doi.org/10.1002/jcp.27170)

Lee SH, Oh HJ, Kim MJ \& Lee BC 2020 Exosomes derived from oviduct cells mediate the EGFR/MAPK signaling pathway in cumulus cells. Journal of Cellular Physiology 235 1386-1404. (https://doi.org/10.1002/ jcp.29058)

Luvoni GC, Chigioni S, Allievi E \& Macis D 2005 Factors involved in vivo and in vitro maturation of canine oocytes. Theriogenology 63 41-59. (https://doi.org/10.1016/j.theriogenology.2004.03.004)

Machtinger R, Laurent LC \& Baccarelli AA 2016 Extracellular vesicles: roles in gamete maturation, fertilization and embryo implantation. Human Reproduction Update 22 182-193. (https://doi.org/10.1093/ humupd/dmv055)

Maillo V, Sanchez-Calabuig MJ, Lopera-Vasquez R, Hamdi M, GutierrezAdan A, Lonergan P \& Rizos D 2016 Oviductal response to gametes and early embryos in mammals. Reproduction 152 R127-R141. (https://doi. org/10.1530/REP-16-0120)

Nickson DA, Boyd JS, Eckersall PD, Ferguson JM, Harvey MJ \& Renton JP 1993 Molecular biological methods for monitoring oocyte maturation and in vitro fertilization in bitches. Journal of Reproduction and Fertility: Supplement 47 231-240.

No J, Zhao M, Lee S, Ock SA, Nam Y \& Hur TY 2018 Enhanced in vitro maturation of canine oocytes by oviduct epithelial cell coculture. Theriogenology 105 66-74. (https://doi.org/10.1016/j. theriogenology.2017.09.002)

Oda K, Matsuoka Y, Funahashi A \& Kitano H 2005 A comprehensive pathway map of epidermal growth factor receptor signaling. Molecular Systems Biology 1 2005.0010. (https://doi.org/10.1038/msb4100014)

Park JY, Su YQ, Ariga M, Law E, Jin SL \& Conti M 2004 EGF-like growth factors as mediators of LH action in the ovulatory follicle. Science 303 682-684. (https://doi.org/10.1126/science.1092463)

Pereira LMC, Bersano PRO, Rocha DD \& Lopes MD 2019 Effect of EGF on expression and localization of maturation-promoting factor, mitogenactivated protein kinase, p34(cdc2) and cyclin B during different culture periods on in vitro maturation of canine oocytes. Reproduction in Domestic Animals 54 325-341. (https://doi.org/10.1111/rda.13365)

Prochazka R, Blaha M \& Nemcova L 2012 Signaling pathways regulating FSH- and amphiregulin-induced meiotic resumption and cumulus cell expansion in the pig. Reproduction 144 535-546. (https://doi. org/10.1530/REP-12-0191)

Quesenberry PJ \& Aliotta JM 2010 Cellular phenotype switching and microvesicles. Advanced Drug Delivery Reviews 62 1141-1148. (https:// doi.org/10.1016/j.addr.2010.06.001)

Rieger D, Grisart B, Semple E, Van Langendonckt A, Betteridge KJ \& Dessy F 1995 Comparison of the effects of oviductal cell co-culture and oviductal cell-conditioned medium on the development and metabolic activity of cattle embryos. Journal of Reproduction and Fertility 105 91-98. (https://doi.org/10.1530/jrf.0.1050091)

Rodrigues TA, Tuna KM, Alli AA, Tribulo P, Hansen PJ, Koh J \& PaulaLopes FF 2019 Follicular fluid exosomes act on the bovine oocyte to improve oocyte competence to support development and survival to heat shock. Reproduction, Fertility, and Development 31 888-897. (https://doi.org/10.1071/RD18450)

Sahin U, Weskamp G, Kelly K, Zhou HM, Higashiyama S, Peschon J, Hartmann D, Saftig P \& Blobel CP 2004 Distinct roles for ADAM10 and 
ADAM17 in ectodomain shedding of six EGFR ligands. Journal of Cell Biology 164 769-779. (https://doi.org/10.1083/jcb.200307137)

Sasseville M, Ritter LJ, Nguyen TM, Liu F, Mottershead DG, Russell DL \& Gilchrist RB 2010 Growth differentiation factor 9 signaling requires ERK1/2 activity in mouse granulosa and cumulus cells. Journal of Cell Science 123 3166-3176. (https://doi.org/10.1242/jcs.063834)

Sekiguchi T, Mizutani T, Yamada K, Kajitani T, Yazawa T, Yoshino M \& Miyamoto K 2004 Expression of epiregulin and amphiregulin in the rat ovary. Journal of Molecular Endocrinology 33 281-291. (https://doi. org/10.1677/jme.0.0330281)

Shimada M, Umehara T \& Hoshino Y 2016 Roles of epidermal growth factor (EGF)-like factor in the ovulation process. Reproductive Medicine and Biology 15 201-216. (https://doi.org/10.1007/s12522-016-0236-x)

Song HJ, Kang EJ, Maeng GH, Ock SA, Lee SL, Yoo JG, Jeon BG \& Rho GJ 2011 Influence of epidermal growth factor supplementation during in vitro maturation on nuclear status and gene expression of canine oocytes. Research in Veterinary Science 91 439-445. (https://doi.org/10.1016/j. rvsc.2010.09.003)

Songsasen N, Yu I \& Leibo SP 2002 Nuclear maturation of canine oocytes cultured in protein-free media. Molecular Reproduction and Development 62 407-415. (https://doi.org/10.1002/mrd.10130)

Su YQ, Sugiura K, Li Q, Wigglesworth K, Matzuk MM \& Eppig JJ 2010 Mouse oocytes enable LH-induced maturation of the cumulus-oocyte complex via promoting EGF receptor-dependent signaling. Molecular Endocrinology 24 1230-1239. (https://doi.org/10.1210/me.2009-0497)

Sugimura S, Ritter LJ, Rose RD, Thompson JG, Smitz J, Mottershead DG \& Gilchrist RB 2015 Promotion of EGF receptor signaling improves the quality of low developmental competence oocytes. Developmental Biology 403 139-149. (https://doi.org/10.1016/j.ydbio.2015.05.008)

Taverna S, Pucci M, Giallombardo M, Di Bella MA, Santarpia M, Reclusa P, Gil-Bazo I, Rolfo C \& Alessandro R 2017 Amphiregulin contained in NSCLC-exosomes induces osteoclast differentiation through the activation of EGFR pathway. Scientific Reports 7 3170. (https://doi. org/10.1038/s41598-017-03460-y)

Tsutsui T 1989 Gamete physiology and timing of ovulation and fertilization in dogs. Journal of Reproduction and Fertility: Supplement 39 269-275.

Valadi H, Ekstrom K, Bossios A, Sjostrand M, Lee JJ \& Lotvall JO 2007 Exosome-mediated transfer of mRNAs and microRNAs is a novel mechanism of genetic exchange between cells. Nature Cell Biology $\mathbf{9}$ 654-659. (https://doi.org/10.1038/ncb1596)

Vannucchi Cl, de Oliveira CM, Marques MG, Assumpcao ME \& Visintin JA 2006 In vitro canine oocyte nuclear maturation in homologous oviductal cell co-culture with hormone-supplemented media. Theriogenology $\mathbf{6 6}$ 1677-1681. (https://doi.org/10.1016/j.theriogenology.2006.01.008)

Yamashita Y, Okamoto M, Kawashima I, Okazaki T, Nishimura R, Gunji Y, Hishinuma M \& Shimada M 2011 Positive feedback loop between prostaglandin E2 and EGF-like factors is essential for sustainable activation of MAPK3/1 in cumulus cells during in vitro maturation of porcine cumulus oocyte complexes. Biology of Reproduction $\mathbf{8 5}$ 1073-1082. (https://doi.org/10.1095/biolreprod.110.090092)

Zhang L, Zhang S, Yao J, Lowery FJ, Zhang Q, Huang WC, Li P, Li M, Wang X, Zhang C et al. 2015 Microenvironment-induced PTEN loss by exosomal microRNA primes brain metastasis outgrowth. Nature $\mathbf{5 2 7}$ 100-104. (https://doi.org/10.1038/nature15376)

Received 10 December 2019

First decision 13 January 2020

Revised manuscript received 22 June 2020

Accepted 10 July 2020 